\title{
Pengaruh Takaran Arang Sekam Padi dan Bokashi Cair terhadap Pertumbuhan dan Hasil Mentimun (Cucumis sativus L.)
}

Ignatio Ivanlendi Cunino ${ }^{\mathrm{a}}$, dan Roberto I. C. O. Taolin ${ }^{\mathrm{b}}$

"Fakultas Pertanian, Universitas Timor, Kefamenanu, TTU - NTT, Indonesia.

${ }^{b}$ Fakultas Pertanian, Universitas Timor, Kefamenanu, TTU - NTT, Indonesia.

\section{Article Info}

Article history:

Received 29 Agustus 2017

Received in revised form 19 Maret 2018

Accepted 4 April 2018

\section{Keywords:}

Arang Sekam Padi

Bokashi Cair

Mentimun

\begin{abstract}
Abstrak
Penelitian ini bertujuan untuk mengetahui pengaruh takaran arang sekam padi dan bokashi cair terhadap pertumbuhan dan hasil mentimun serta mengetahui takaran arang sekam padi dan bokashi cair yang tepat untuk pertumbuhan dan hasil mentimun yang optimum. Rancangan yang digunakan dalam penelitian ini adalah Rancangan Acak Kelompok (RAK) faktorial yang terdiri dari dua faktor dengan tiga kali ulangan. Faktor pertama adalah takaran arang sekam padi yang terdiri dari tiga aras yaitu tanpa arang sekam padi atau $0 \mathrm{t} / \mathrm{ha}, 5 \mathrm{t} / \mathrm{ha}$ dan 10 t/ha. Faktor kedua adalah takaran bokashi cair yang terdiri dari tiga aras yaitu tanpa bokashi cair atau $0 \mathrm{ml}, 2 \mathrm{ml}$ dan $4 \mathrm{ml}$. Hasil penelitian menunjukkan pengaruh interaksi antara takaran arang sekam padi dan bokashi cair hanya terjadi terhadap suhu tanah 35 HST. Takaran arang sekam padi berpengaruh nyata terhadap suhu tanah 14 HST, berat per buah, berat buah per tanaman, jumlah buah per petak, berat segar berangkasan dan indeks panen. Takaran bokashi cair berpengaruh nyata terhadap berat buah per petak panen I dan total panen, berat segar berangkasan dan berat kering berangkasan. Pemberian arang sekam padi 5 t/ha memberikan hasil terbaik berupa 55694 buah setiap hektar dengan berat 16,250 ton. Pemberian bokashi cair $4 \mathrm{ml}$ per tanaman memberikan hasil 53333 buah setiap hektar dengan berat 16,931 ton. (2018 dipublikasikan oleh Savana Cendana.
\end{abstract}

\section{Pendahuluan}

Mentimun (Cucumis sativus, L.) merupakan salah satu jenis sayuran dari keluarga labu-labuan (Cucurbitaceae) yang sudah populer di dunia. Menuru sejarah tanaman mentimun berasal dari Benua Asia. Beberapa sumber literatur menyebutkan daerah asal tanaman mentimun adalah Asia Utara, tetapi sebagian lagi menduga berasal dari Asia Selatan (Rukmana, 1994). Tanaman mentimun berasal dari bagian Utara India yakni tepatnya di lereng Gunung Himalaya, yang kemudian menyebar ke wilayah Mediteran. Di wilayah tersebut, telah ditemukan jenis mentimun liar yakni Cucumie hordwichi (Tyndall, 1987). Di Indonesia, tanaman mentimun ditanam di dataran rendah. Daerah penyebaran yang menjadi pusat pertanaman mentimun adalah Provinsi Jawa Barat, Daerah Istimewa Aceh, Bengkulu, Jawa Timur dan Jawa Tengah. Pengembangan budidaya mentimun menjadi urutan ke empat setelah cabai, kacang panjang dan bawang merah dari jenis sayuran komersial yang dihasilkan di Indonesia (Rukmana, 1994).

Dalam proses pengembangan tanaman mentimun sering mengalami kendala, terutama dalam hal sifat fisik dan kimia tanah. Tanah yang kurang subu menyebabkan produksi menurun. Untuk itu dalam penanaman mutlak diperlukan pengolahan tanah dan penambahan unsur hara. Dalam hal ini dapat dilakukan pemanfaatan arang sekam padi dan bokashi cair sebagai solusi yang dapat dilakukan

Bahan organik merupakan sumber energi atau makanan bagi mikroorganisme yang mempunyai peranan penting dalam kegiatan reduksi oksidasi pada tanah sulfat masam. Bahan organik tidak hanya berperan dalam memperbaiki sifat fisik tanah, tetapi sekaligus berperan dalam menekan oksidasi pirit. Bahan organik mempunyai fungsi untuk menurunkan atau mempertahankan suasana reduksi karena dapat mempertahankan kebasaan tanah sehingga oksidasi pirit dapat ditekan sehingga $\mathrm{pH}$ tanah meningkat (Noor, 2004).

Pemberian bahan organik yang berasal dari sampah organik, kotoran ternak, jerami padi, arang sekam padi atau gulma air (azolla) yang sudah membusuk berperan besar dalam mengurangi kelarutan unsur-unsur beracun, sumber hara bagi tanaman dan sumber energi dalam menunjang aktivitas mikroorganisme tanah selain dapat meningkatkan efisiensi penggunaan pupuk anorganik (Syahruzad, 1987). Sekam dan arang sekam memiliki fungsi mengikat logam berat. Selain itu sekam berfungsi untuk menggemburkan tanah sehingga bisa mempermudah akar tanaman menyerap unsur hara, abu sekam dianggap memiliki daya serap terhadap air sedikit, tetapi aerasi udaranya sangat baik.

Menurut Radjagukguk \& Jutono, (1983), arang hasil pembakaran serasah tanaman dapat meningkatkan $\mathrm{pH}$ tanah dan suplai unsur-unsur hara terutama $\mathrm{Ca}$ Mg, K dan N. Nurita \& Jumberi, (1997) menyatakan bahwa arang sekam juga dapat dijadikan bahan amelioran sebagai penyedia $\mathrm{Ca}, \mathrm{Mg}$ dan $\mathrm{K}$ dan pemberian arang sekam dapat meningkatkan kandungan $\mathrm{Ca}$ dan $\mathrm{Mg}$ dalam tanah. Penelitian Kolo \& Raharjo, (2016) membuktikan bahwa arang sekam berpengaruh pada pertumbuhan dan hasil tomat, demikian juga penelitian Lolomsait, (2016) menunjukkan bahwa arang sekam berpengaruh pada diameter batang dan panjang buah cabe merah.

Menurut Higa, (1991) bokashi adalah salah satu kata dari bahasa Jepang yang berarti bahan organik yang telah difermentasikan. Bokashi dibuat dengan memfermentasikan bahan organik seperti sekam padi, jerami, serbuk gergaji atau limbah pasar. Penggunaan effektif microorganism (EM-4) merupakan salah satu cara yang tepat untuk meningkatkan jumlah mikroorganisme di dalam tanah karena EM-4 merupakan inokulum mikroba yang dapat digunakan untuk membantu proses dekomposisi bahan organik. EM-4 tidak mengandung bahan kimia yang berbahaya dan biasanya sudah tersedia di dalam tanah sehingga tidak akan merusak lingkungan.

Berdasarkan uraian di atas maka perlu dilakukan penelitian untuk mengkaji pengaruh takaran arang sekam padi dan bokashi cair terhadap pertumbuhan dan hasil mentimun. Tujuan penelitian adalah untuk mengetahui 1) pengaruh takaran arang sekam padi dan bokashi cair terhadap pertumbuhan dan hasil mentimun dan 2) takaran arang sekam padi dan bokashi cair yang tepat untuk pertumbuhan dan hasil mentimun yang optimum.

\section{Metode}

Penelitian ini dilaksanakan pada bulan Juni sampai Agustus 2017 di kebun Bansone, Kelurahan Bansone, Kecamatan Kota Kefamenanu, Kabupaten TTU. Rancangan yang digunakan dalam penelitian ini adalah Rancangan Acak Kelompok (RAK) faktorial yang terdiri dari dua faktor dengan tiga kali ulangan. Faktor pertama adalah takaran arang sekam padi (K) yang terdiri dari tiga aras yaitu tanpa arang sekam padi atau $0 \mathrm{t} / \mathrm{ha}\left(\mathrm{k}_{1}\right), 5 \mathrm{t} / \mathrm{ha}\left(\mathrm{k}_{2}\right)$ dan $10 \mathrm{t} / \mathrm{ha}\left(\mathrm{k}_{3}\right)$. Faktor kedua adalah takaran bokashi cair (B) yang terdiri dari tiga aras yaitu tanpa bokashi cair atau $0 \mathrm{ml}\left(\mathrm{b}_{1}\right), 2 \mathrm{ml}\left(\mathrm{b}_{2}\right)$ dan $4 \mathrm{ml}\left(\mathrm{b}_{3}\right)$. Kombinasi perlakuannya adalah $\mathrm{k}_{1} \mathrm{~b}_{1}, \mathrm{k}_{1} \mathrm{~b}_{2}, \mathrm{k}_{1} \mathrm{~b}_{3}, \mathrm{k}_{2} \mathrm{~b}_{1}, \mathrm{k}_{2} \mathrm{~b}_{2}, \mathrm{k}_{2} \mathrm{~b}_{3}, \mathrm{k}_{3} \mathrm{~b}_{1}, \mathrm{k}_{3} \mathrm{~b}_{2}$ dan $\mathrm{k}_{3} \mathrm{~b}_{3}$

Benih yang digunakan dalam penelitian ini adalah benih mentimun varietas F1 Karakatau yang dibeli dari toko sarana produksi pertanian. Benih yang dibutuhkan dalam penelitian ini sebanyak 2.160 dengan benih cadangan sebanyak $10 \%$ sehingga jumlah benih yang disiapkan sebanyak 2.376 benih.

Tanah terlebih dahulu dibersihkan dari gulma dan serta vegetasi lainnya untuk selanjutnya dilakukan pengolahan. Pengolahan tanah dilakukan dengan menggunakan cangkul, kemudian dilanjutkan dengan penggemburan tanah. Lahan yang digunakan berukuran panjang $24 \mathrm{~m}$ dan lebar $14 \mathrm{~m}$ dengan luas 336 $\mathrm{m}^{2}$. Lahan dibagi dalam tiga blok dan pada masing-masing blok dibuat sembilan petak percobaan dengan ukuran panjang $4 \mathrm{~m}$, lebar $2 \mathrm{~m}$ dan tinggi $20 \mathrm{~cm}$ sehingga secara keseluruhan terdapat 27 petak. Jarak antara petak $0,5 \mathrm{~m}$ dan jarak antara blok $1 \mathrm{~m}$. Pada setiap blok, petak, tanaman sampel dan tanaman korban diberikan label menggunakan tiang bambu dan seng.

Proses pembakaran arang sekam dilakukan dengan tahapan sebagai berikut:

a. Pilih lokasi pembakaran yang jauh dari perumahan atau jalan, karena prose pembakaran sekam padi akan menimbulkan asap yang tebal. Sebaiknya alas tempat pembakaran terbuat dari lantai keras yang tahan panas, atau alasi bagian bawah dengan pelat seng sebelum melakukan pembakaran. Hal in untuk memudahkan pengambilan arang sekam.

b. Buat api unggun seukuran silinder yang telah kita buat sebelumnya. Bahan bakarnya bisa menggunakan kertas koran, kayu bakar atau daun-daun kering. Kemudian nyalakan api, lalu tutup api tersebut dengan silinder yang telah diberi cerobong asap tadi.

c. Timbun ruang pembakaran silinder yang di dalamnya sudah ada nyala api dengan beberapa karung sekam padi. Penimbunan dilakukan menggunung ke atas setinggi kurang lebih 1 meter dengan puncak timbunan cerobong asap yang menyembul keluar.

d. Setelah 20-30 menit atau saat puncak timbunan sekam padi terlihat menghitam, naikkan sekam yang masih berwarna coklat di bawah ke arah puncak. Lakukan terus sampai semua sekam padi menghitam sempurna.

e. Setelah semua sekam berubah menjadi hitam, siram dengan air hingga merata. Penyiraman dilakukan untuk menghentikan proses pembakaran. Apabila proses pembakaran tidak dihentikan maka arang sekam akan berubah menjadi abu.

f. Setelah disiram dan suhunya menurun, bongkar gunungan arang sekam dan keringkan. Kemudian masukkan ke dalam karung dan simpan di tempat kering.

Pemberian abu sekam padi dilakukan pada saat dua -14 HST (Hari Setelah Tanam) dengan cara disebar merata di permukaan petak kemudian dicampur dengan tanah. Takaran abu sekam padi disesuaikan dengan perlakuan yaitu pada sembilan petak tidak diberikan abu sekam padi, pada sembilan petak menggunakan takaran $5 \mathrm{t} / \mathrm{ha}$ atau $10 \mathrm{~kg}$ per petak dan pada sembilan petak menggunakan takaran $10 \mathrm{t} / \mathrm{ha}$ atau $10 \mathrm{~kg}$ per petak. Total kebutuhan abu sekam padi sebanyak $405 \mathrm{~kg}$. 
Penanaman dilakukan pada saat sore hari, dengan cara tugal sedalam \pm 3 $\mathrm{cm}$. Benih ditanam dua butir per lubang tanam yang dicampur dengan Furadan kemudian ditutup dengan tanah. Jarak tanam yang digunakan adalah 50 x $40 \mathrm{~cm}$. Jumlah tanaman dalam setiap petak adalah 40 tanaman dengan jumlah keseluruhan 1.080 tanaman

Pemberian pupuk cair dilakukan dengan cara disemprot menggunakan hand sprayer yang diberikan dua kali selama penelitian yaitu pada saat tanaman berumur $10 \mathrm{HST}$ dan pada saat tanaman memasuki fase generatif, setiap kali pemberian menggunakan setengah dari takaran. Takaran yang digunakan disesuaikan dengan perlakuan yaitu $1 \mathrm{ml}$ per tanaman dan pada sembilan petak menggunakan takaran $2 \mathrm{ml}$ per tanaman. Kebutuhan total bokashi cair dalam penelitian ini adalah $6480 \mathrm{ml}$. Bokashi cair yang telah siap diaplikasikan dengan cara disemprot pada tanaman sesuai dengan perlakuan.

Pemasangan ajir dilakukan sebelum tanam, agar tidak mengganggu atau merusak perakaran tanaman mentimun. Ajir yang digunakan adalah bambu yang berukuran tinggi $2 \mathrm{~m}$ yang dipasang secara berpasangan kemudian di atas ajir dibentangi dengan tali rafia.

Pemeliharaan meliputi penyiraman, penyulaman, penyiangan serta pengendalian hama dan penyakit tanaman. Penyiraman dilakukan menggunakan gembor pada pagi dan sore hari. Penyulaman dilakukan pada saat tanaman berumur 10 HST. Penyulaman dilakukan dengan cara mengganti bibit yang mati atau rusak dengan bibit cadangan yang telah disiapkan. Penyiangan terhadap gulma dilakukan dengan mencabutnya dan bila perlu dibantu dengan alat pencungkil, namun dilakukan hati-hati agar jangan sampai akar tanaman terganggu. Pengendalian HPT dilakukan apabila tanaman mengalami serangan hama dan penyakit.

Panen mentimun dilakukan setelah tanaman ditandai dengan ciri buah yang telah berukuran besar. Panen dilakukan dengan cara memotong tangkai buah dengan pisau atau gunting. Pemanenan dilakukan tiga kali dengan jarak waktu satu minggu, panen yang ketiga dilakukan secara rampasan atau panen semua buah. Umur panen mentimum varietas Karak atau adalah 105 hari. Parameter yang diukur adalah sebagai berikut:

a. Suhu Tanah $\left({ }^{\circ} \mathrm{C}\right)$

Pengukuran suhu tanah dilakukan empat kali selama penelitian yakni -1 HST, 14 HST, 35 HST dan 56 HST, menggunakan termometer suhu tanah, dengan cara ditancapkan pada kedalaman tanah $5 \mathrm{~cm}$ selama 3 menit pada tiga titik untuk setiap petak. Pengukuran dilakukan pada siang hari pukul 12.00-14.00 WITA. Pengukuran suhu dilakukan sesuai petunjuk Budhyastoro et al., (2006).

b. Kadar Lengas Tanah (\%)

Sampel tanah diambil dengan cara menggali sedalam $5 \mathrm{~cm}$ pada tiga titik untuk setiap petak. Sampel tanah yang sudah diambil berbentuk gumpalan +2 $\mathrm{cm}$, kemudian disimpan dalam wadah plastik yang ditandai dengan label, kemudian ditimbang untuk mengetahui berat basah, selanjutnya dioven selama 48 jam pada suhu $105{ }^{\circ} \mathrm{C}$, kemudian ditimbang untuk mengetahui berat kering. Pengukuran dilakukan sebanyak empat kali selama penelitian yakni -1 HST, 14 HST, 35 HST dan 56 HST. Kadar lengas tanah dihitung dengan rumus sesuai petunjuk (Poerwowidodo, 1993).

c. Tinggi Tanaman $(\mathrm{cm})$

Tinggi tanaman diukur dari pangkal batang sampai ujung daun paling tinggi, pengukuran menggunakan penggaris centimeter. Pengukuran dilakukan pada lima tanaman sampel saat berumur 14 HST, 35 HST dan 56 HST.

d. Diameter Batang $(\mathrm{mm})$

Pengukuran diameter batang dilakukan dengan menggunakan jangka sorong dengan cara menjepit pada bagian batang $(1 \mathrm{~cm}$ di atas pangkal batang) dari lima tanaman sampel pada setiap petak. Pengukuran dilakukan pada saat tanaman berumur 14 HST, 35 HST dan 56 HST

e. Luas Daun $\left(\mathrm{cm}^{2}\right)$

Pengukuran luas daun dilakukan saat tanaman berumur 56 HST menggunakan metode fotografi dengan cara mengambil semua daun pada lima tanaman sampel pada tiap petak, kemudian daun dipotret menggunakan kamera digital. Luas area daun kemudian dihitung menggunakan program ImageJ versi 1.410 .

\section{f. Diameter Buah (mm)}

Pengukuran diameter buah dilakukan dengan menggunakan jangka sorong dengan cara menjepit pada bagian pangkal, tengah dan ujung buah kemudian dirata-ratakan. Buah yang diukur adalah semua buah yang dipanen dari lima tanaman sampel pada setiap petak kemudian dirata-ratakan. Pengukuran dilakukan setiap kali panen kemudian dirata-ratakan untuk memperoleh ukuran diameter buah.

g. Panjang Buah $(\mathrm{cm})$

Pengukuran panjang buah dilakukan dengan menggunakan mistar yang diukur dari pangkal hingga ujung buah. Buah yang diukur adalah semua buah yang dipanen dari lima tanaman sampel pada setiap petak kemudian dirataratakan. Pengukuran dilakukan setiap kali panen kemudian dirata-ratakan untuk memperoleh ukuran panjang buah.

\section{h. Berat Per Buah (g)}

Berat Per buah diukur dengan cara menimbang buah mentimun menggunakan timbangan analitik. Buah yang ditimbang adalah semua buah yang dipanen dari setiap tanaman sampel pada semua petak kemudian dirata-ratakan dengan cara berat total dibagi dengan jumlah buah. Pengukuran dilakukan setiap kali panen kemudian dirata-ratakan untuk memperoleh ukuran berat per buah. i. Jumlah Buah Per Tanaman

Buah yang dipanen dari lima tanaman sampel dihitung kemudian dirataratakan. Perhitungan dilakukan setiap kali panen kemudian dijumlahkan untuk mendapatkan jumlah buah per tanaman.

j. Berat Buah Per Tanaman (g)

Berat buah per tanaman diukur dengan cara menimbang buah menggunakan timbangan duduk. Buah yang ditimbang adalah semua buah yang dipanen dari lima tanaman sampel pada setiap petak kemudian dirata-ratakan dengan cara berat total dibagi dengan jumlah tanaman sampel. Pengukuran dilakukan setiap kali panen kemudian dijumlahkan untuk memperoleh ukuran berat buah per tanaman.

k. Jumlah Buah Per Petak

Buah yang dipanen dari semua tanaman setiap petak dihitung. Perhitungan dilakukan setiap kali panen kemudian dijumlahkan untuk mendapatkan jumlah buah per petak total panen. Hasil perhitungan dikonversi untuk luas lahan satu hektar.

1. Berat Buah Per Petak (t/ha)

Berat buah per petak diukur dengan cara menimbang buah menggunakan timbangan gantung. Buah yang ditimbang adalah semua buah yang dipanen dari setiap petak. Pengukuran dilakukan setiap kali panen kemudian dijumlahkan untuk memperoleh ukuran berat buah per petak total panen kemudian dikonversi ke t/ha.

m. Berat Segar Berangkasan ( $t / h a)$

Berat segar berangkasan diukur dengan cara menimbang berangkasan semua tanaman dalam setiap petak yang telah dipanen kemudian dikonversikan ke satuan $\mathrm{t} / \mathrm{ha}$. Pengukuran menggunakan timbangan duduk.

n. Berat Kering Berangkasan (t/ha)

Berat kering berangkasan diukur dengan cara menimbang berangkasan semua tanaman dalam setiap petak yang telah dipanen dan dijemur selama satu minggu kemudian dikonversikan ke satuan t/ha. Pengukuran menggunakan timbangan duduk.

o. Indeks Panen (\%)

Indeks panen dihitung dengan cara membandingkan berat bagian tanaman yang bernilai ekonomis dengan berat bagian seluruh tanaman kemudian dikonversikan ke satuan \%. Indeks panen dihitung dengan rumus sesuai petunjuk Yadav et al., (1979).

Data hasil pengamatan kemudian dianalisis dengan menggunakan sidik ragam (Anova) Rancangan Acak Kelompok (RAK). Rata-rata perlakuan selanjutnya diuji lanjut dengan menggunakan Duncan Multiple Range Test (DMRT) dengan tingkat signifikasi 5\% sesuai petunjuk Gomez \& Gomez, (1984). Analisis data menggunakan program SAS 9.1.

\section{Hasil dan Pembahasan}

\subsection{Suhu Tanah}

Hasil sidik ragam (Anova) menunjukkan bahwa terjadi interaksi antara takaran arang sekam padi dan takaran bokashi cair terhadap suhu tanah 35 HST dimana suhu tanah pada petak yang diberikan arang sekam padi dengan takaran $5 \mathrm{t} /$ ha tetapi tidak diberikan bokashi cair paling tinggi dan berbeda nyata dengan suhu tanah pada petak yang diberikan arang sekan padi dengan takaran yang sama kemudian diberikan bokashi cair dengan takaran $2 \mathrm{ml}$ per tanaman serta suhu tanah pada petak yang diberikan arang sekan padi dengan takaran $10 \mathrm{t} / \mathrm{ha}$ kemudian diberikan bokashi cair dengan takaran $2 \mathrm{ml}$ maupun $4 \mathrm{ml}$, tetapi tidak berbeda nyata dengan suhu tanah dari kombinasi perlakuan lainnya. Saat 14 HST dan 56 HST tidak terjadi interaksi antara takaran arang sekam padi dan takaran bokashi cair.

Tabel 1. Suhu Tanah $\left({ }^{\circ} \mathrm{C}\right)$

\begin{tabular}{|c|c|c|c|c|c|}
\hline \multirow{2}{*}{$\begin{array}{c}\text { Waktu } \\
\text { Pengamatan }\end{array}$} & \multirow{2}{*}{ Arang Sekam Padi } & \multicolumn{3}{|c|}{ Bokashi Cair } & \multirow{2}{*}{ Rerata } \\
\hline & & Kontrol & $2 \mathrm{ml}$ & $4 \mathrm{ml}$ & \\
\hline \multirow{4}{*}{$14 \mathrm{HSS}$} & Kontrol & 29,1 & 28,8 & 28,9 & $28,9 \mathrm{a}$ \\
\hline & $5 \mathrm{t} / \mathrm{ha}$ & 28,0 & 28,9 & 28,3 & $28,4 \mathrm{ab}$ \\
\hline & $10 \mathrm{t} / \mathrm{ha}$ & 28,4 & 27,8 & 27,4 & $27,9 \mathrm{~b}$ \\
\hline & Rerata & $28,5 \mathrm{a}$ & $28,5 \mathrm{a}$ & $28,2 \mathrm{a}$ & $(-)$ \\
\hline \multirow{4}{*}{$35 \mathrm{HSS}$} & Kontrol & $30,1 \mathrm{abc}$ & $30,3 a b c$ & $31,0 \mathrm{abc}$ & $30,5 \mathrm{a}$ \\
\hline & $5 \mathrm{t} / \mathrm{ha}$ & $31,6 \mathrm{a}$ & $28,5 \mathrm{c}$ & $30,9 \mathrm{abc}$ & $30,3 \mathrm{a}$ \\
\hline & $10 \mathrm{t} / \mathrm{ha}$ & $28,9 \mathrm{bc}$ & $31,3 \mathrm{ab}$ & $28,7 \mathrm{c}$ & $29,7 \mathrm{a}$ \\
\hline & Rerata & $30,2 \mathrm{a}$ & $30,1 \mathrm{a}$ & $30,2 \mathrm{a}$ & $(+)$ \\
\hline \multirow{4}{*}{56 HSS } & Kontrol & 29,9 & 30,5 & 29,8 & $30,0 \mathrm{a}$ \\
\hline & $5 \mathrm{t} / \mathrm{ha}$ & 29,7 & 29,3 & 29,6 & $29,5 \mathrm{a}$ \\
\hline & $10 \mathrm{t} / \mathrm{ha}$ & 29,5 & 28,9 & 29,3 & $29,3 \mathrm{a}$ \\
\hline & Rerata & $29,7 \mathrm{a}$ & 29,6 a & 29,6 a & $(-)$ \\
\hline
\end{tabular}

Keterangan: Angka pada baris dan kolom yang diikuti dengan huruf yang sama tidak berbeda nyata menurut uji DMRT $\alpha 5 \%$; $(-)$ : Tidak terjadi interaksi antar faktor; $(+)$ : Terjadi interaksi antar faktor.

\subsection{Kadar Lengas Tanah}

Hasil sidik ragam (Anova) menunjukkan bahwa tidak terjadi interaksi antara takaran arang sekam padi dan takaran bokashi cair terhadap kadar lengas tanah setiap waktu pengamatan. Takaran arang sekam padi juga tidak berpengaruh terhadap kadar lengas tanah setiap waktu pengamatan tetapi data Tabel 2. menunjukkan bahwa saat pengamatan 14 HST dan 56 HST, kadar lengas tanah 
pada petak yang tidak diberikan arang sekam padi cenderung lebih tinggi sedangkan saat pengamatan 35 HST kadar lengas tanah pada petak yang diberikan arang sekam padi dengan takaran 5 t/ha cenderung lebih tinggi.

Pemberian bokashi cair tidak berpengaruh nyata terhadap kadar lengas tanah setiap waktu pengamatan tetapi saat 14 HST dan 35 HST, kadar lengas tanah pada petak yang tidak diberikan bokashi cair cenderung lebih tinggi, sedangkan pada pengamatan terakhir kadar lengas pada petak yang diberikan bokashi cair dengan takaran $2 \mathrm{ml}$ per tanaman cenderung lebih tinggi.

Tabel 2. Kadar Lengas Tanah (\%)

\begin{tabular}{cccccc}
\hline Waktu & \multirow{2}{*}{ Arang Sekam Padi } & \multicolumn{3}{c}{ Bokashi Cair } & \multirow{2}{*}{ Rerata } \\
\cline { 3 - 5 } & & Kontrol & $2 \mathrm{ml}$ & $4 \mathrm{ml}$ & \\
\hline \multirow{4}{*}{$14 \mathrm{HSS}$} & Kontrol & 22,0 & 29,0 & 16,2 & $22,4 \mathrm{a}$ \\
& $5 \mathrm{t} / \mathrm{ha}$ & 28,1 & 15,0 & 15,7 & $19,6 \mathrm{a}$ \\
& $10 \mathrm{t} / \mathrm{ha}$ & 15,7 & 15,7 & 16,9 & $16,1 \mathrm{a}$ \\
\hline \multirow{4}{*}{$35 \mathrm{HSS}$} & Rerata & $21,9 \mathrm{a}$ & $19,9 \mathrm{a}$ & $16,3 \mathrm{a}$ & $(-)$ \\
\cline { 2 - 5 } & Kontrol & 26,0 & 28,2 & 29,7 & $28,0 \mathrm{a}$ \\
& $5 \mathrm{t} / \mathrm{ha}$ & 36,2 & 32,3 & 25,9 & $31,5 \mathrm{a}$ \\
& $10 \mathrm{t} / \mathrm{ha}$ & 35,7 & 22,2 & 31,2 & $29,7 \mathrm{a}$ \\
\hline \multirow{4}{*}{$56 \mathrm{HSS}$} & Rerata & $32,6 \mathrm{a}$ & $27,6 \mathrm{a}$ & $28,9 \mathrm{a}$ & $(-)$ \\
\cline { 2 - 5 } & Kontrol & 17,4 & 20,9 & 16,8 & $18,3 \mathrm{a}$ \\
& $5 \mathrm{t} / \mathrm{ha}$ & 16,9 & 25,5 & 11,0 & $17,8 \mathrm{a}$ \\
& $10 \mathrm{t} / \mathrm{ha}$ & 15,1 & 15,7 & 23,5 & $18,1 \mathrm{a}$ \\
\hline & Rerata & $16,4 \mathrm{a}$ & $20,7 \mathrm{a}$ & $17,1 \mathrm{a}$ & $(-)$ \\
\hline
\end{tabular}

Keterangan: Angka pada baris dan kolom yang diikuti dengan huruf yang sama tidak berbeda nyata menurut uji DMRT $\alpha 5 \%$; $(-)$ : Tidak terjadi interaksi antar faktor.

\subsection{Tinggi Tanaman}

Hasil sidik ragam (Anova) menunjukkan bahwa tidak terjadi interaksi antara takaran arang sekam padi dan takaran bokashi cair terhadap tinggi tanaman setiap waktu pengamatan. Takaran arang sekam padi juga tidak berpengaruh terhadap tinggi tanaman setiap waktu pengamatan tetapi data Tabel 3. menunjukkan bahwa saat pengamatan 14 HST, tanaman yang tidak diberikan arang sekam padi sama tinggi dengan tanaman yang diberikan arang sekam padi dengan takaran 5 t/ha dan lebih tinggi dari tanaman yang diberikan arang sekam dengan takaran 10 t/ha. Saat 35 HST, tanaman yang diberikan arang sekam padi dengan takaran $5 \mathrm{t} / \mathrm{ha}$ cenderung lebih tinggi sedangkan tanaman yang diberikan arang sekam padi dengan takaran 10 t/ha paling pendek. Saat 56 HST, tanaman yang tidak diberikan arang sekam padi cenderung lebih tinggi sedangkan tanaman yang diberikan arang sekam padi dengan takaran 10 t/ha paling pendek.

Pemberian bokashi cair tidak berpengaruh nyata terhadap tinggi tanaman setiap waktu pengamatan tetapi saat 14 HST dan 35 HST, tanaman yang tidak diberikan bokashi cair cenderung lebih tinggi, sedangkan pada pengamatan terakhir tanaman yang diberikan bokashi cair dengan takaran $4 \mathrm{ml}$ per tanaman cenderung lebih tinggi.

Tabel 3. Tinggi Tanaman $(\mathrm{cm})$

\begin{tabular}{cccccc}
\hline Waktu & \multirow{2}{*}{ Arang Sekam Padi } & \multicolumn{3}{c}{ Bokashi Cair } & \multirow{2}{*}{ Rerata } \\
\cline { 3 - 5 } & Kongamatan & 13,5 & 13,2 & 12,8 & $13,2 \mathrm{a}$ \\
\multirow{4}{*}{$14 \mathrm{HST}$} & $5 \mathrm{t} / \mathrm{ha}$ & 13,3 & 13,3 & 13,1 & $13,2 \mathrm{a}$ \\
& $10 \mathrm{t} / \mathrm{ha}$ & 13,1 & 13,0 & 13,3 & $13,1 \mathrm{a}$ \\
\hline \multirow{4}{*}{$35 \mathrm{HST}$} & Rerata & $13,3 \mathrm{a}$ & $13,2 \mathrm{a}$ & $13,0 \mathrm{a}$ & $(-)$ \\
\hline & Kontrol & 82,9 & 82,5 & 83,3 & $82,9 \mathrm{a}$ \\
& $5 \mathrm{t} / \mathrm{ha}$ & 86,6 & 83,9 & 80,6 & $83,7 \mathrm{a}$ \\
& $10 \mathrm{t} / \mathrm{ha}$ & 80,4 & 82,1 & 81,3 & $81,2 \mathrm{a}$ \\
\hline \multirow{4}{*}{56 HST } & Rerata & $83,3 \mathrm{a}$ & $82,8 \mathrm{a}$ & $81,7 \mathrm{a}$ & $(-)$ \\
\hline & Kontrol & 98,4 & 98,4 & 98,4 & $98,4 \mathrm{a}$ \\
& $5 \mathrm{t} / \mathrm{ha}$ & 98,0 & 97,9 & 98,7 & $98,2 \mathrm{a}$ \\
& $10 \mathrm{t} / \mathrm{ha}$ & 98,6 & 85,7 & 98,5 & $94,3 \mathrm{a}$ \\
\hline & Rerata & $98,3 \mathrm{a}$ & $94,0 \mathrm{a}$ & $98,5 \mathrm{a}$ & $(-)$ \\
\hline
\end{tabular}

Keterangan: Angka pada baris dan kolom yang diikuti dengan huruf yang sama tidak berbeda nyata menurut uji DMRT $\alpha 5 \% ;(-)$ : Tidak terjadi interaksi antar faktor.

\subsection{Diameter Batang}

Hasil sidik ragam (Anova) menunjukkan bahwa tidak terjadi interaksi antara takaran arang sekam padi dan takaran bokashi cair terhadap diameter batang setiap waktu pengamatan. Takaran arang sekam padi juga tidak berpengaruh terhadap diameter batang setiap waktu pengamatan tetapi data Tabel 4 menunjukkan bahwa saat pengamatan 14 HST dan 35 HST, batang tanaman yang diberikan arang sekam padi dengan takaran 5 t/ha cenderung lebih besar sedangkan saat 56 HST, batang tanaman yang tidak diberikan arang sekam padi cenderung lebih besar sedangkan batang tanaman yang diberikan arang sekam padi dengan takaran $5 \mathrm{t}$ /ha paling kecil.

Pemberian bokashi cair tidak berpengaruh nyata terhadap diameter batang setiap waktu pengamatan tetapi saat $14 \mathrm{HST}$, batang tanaman yang diberikan bokashi cair dengan takaran $4 \mathrm{ml}$ per tanaman cenderung lebih besar, sedangkan pada pengamatan 35 HST dan 56 HST, batang tanaman yang diberikan bokashi cair dengan takaran $2 \mathrm{ml}$ per tanaman cenderung lebih besar.
Tabel 4. Diameter Batang (mm)

\begin{tabular}{cccccc}
\hline \multirow{2}{*}{$\begin{array}{c}\text { Waktu } \\
\text { Pengamatan }\end{array}$} & \multirow{2}{*}{ Arang Sekam Padi } & \multicolumn{3}{c}{ Bokashi Cair } & \multirow{2}{*}{ Rerata } \\
\cline { 2 - 5 } & & Kontrol & $2 \mathrm{ml}$ & $4 \mathrm{ml}$ & \\
\hline \multirow{3}{*}{$14 \mathrm{HST}$} & Kontrol & 1,2 & 1,3 & 1,2 & $1,2 \mathrm{a}$ \\
& $5 \mathrm{t} / \mathrm{ha}$ & 1,4 & 1,3 & 1,3 & $1,3 \mathrm{a}$ \\
& $10 \mathrm{t} / \mathrm{ha}$ & 1,1 & 1,2 & 1,3 & $1,2 \mathrm{a}$ \\
\cline { 2 - 5 } & Rerata & $1,2 \mathrm{a}$ & $1,2 \mathrm{a}$ & $1,3 \mathrm{a}$ & $(-)$ \\
\hline \multirow{3}{*}{$35 \mathrm{HST}$} & Kontrol & 4,1 & 4,7 & 3,9 & $4,2 \mathrm{a}$ \\
& $5 \mathrm{t} / \mathrm{ha}$ & 4,6 & 4,3 & 4,3 & $4,4 \mathrm{a}$ \\
& $10 \mathrm{t} / \mathrm{ha}$ & 4,3 & 4,5 & 3,3 & $4,0 \mathrm{a}$ \\
\hline \multirow{3}{*}{$56 \mathrm{HST}$} & Rerata & $4,3 \mathrm{a}$ & $4,5 \mathrm{a}$ & $3,8 \mathrm{a}$ & $(-)$ \\
& Kontrol & 8,1 & 8,4 & 8,3 & $8,3 \mathrm{a}$ \\
& $5 \mathrm{t} / \mathrm{ha}$ & 8,2 & 8,1 & 8,0 & $8,1 \mathrm{a}$ \\
& $10 \mathrm{t} / \mathrm{ha}$ & 8,2 & 8,2 & 8,3 & $8,2 \mathrm{a}$ \\
\hline \multirow{2}{*}{ Keterannnn} & Rerata & $8,2 \mathrm{a}$ & $8,3 \mathrm{a}$ & $8,2 \mathrm{a}$ & $(-)$ \\
\hline
\end{tabular}

Keterangan: Angka pada baris dan kolom yang diikuti dengan huruf yang sama tidak berbeda nyata menurut uji DMRT $\alpha 5 \%$; $(-)$ : Tidak terjadi interaksi antar faktor.

\subsection{Luas Daun}

Hasil sidik ragam (Anova) menunjukkan bahwa tidak terjadi interaksi antara takaran arang sekam padi dan takaran bokashi cair terhadap luas daun. Takaran arang sekam padi juga tidak berpengaruh terhadap luas daun tetapi data Tabel 5 menunjukkan bahwa daun dari tanaman yang diberikan arang sekam padi dengan takaran $5 \mathrm{t} /$ ha cenderung lebih luas sedangkan daun dari tanaman yang tidak diberikan arang sekam padi paling sempit. Pemberian bokashi cair tidak berpengaruh nyata terhadap luas daun tetapi daun tanaman yang diberikan bokashi cair dengan takaran $2 \mathrm{ml}$ per tanaman cenderung lebih luas sedangkan daun tanaman yang diberikan bokashi cair dengan takaran $4 \mathrm{ml}$ per tanaman paling sempit.

Tabel 5. Luas Daun $\left(\mathrm{cm}^{2}\right)$

\begin{tabular}{ccccc}
\hline \multirow{2}{*}{ Arang Sekam Padi } & \multicolumn{3}{c}{ Bokashi Cair } & \multirow{2}{*}{ Rerata } \\
\cline { 2 - 4 } & Kontrol & $2 \mathrm{ml}$ & $4 \mathrm{ml}$ & \\
\hline Kontrol & 363 & 282 & 291 & $312 \mathrm{a}$ \\
$5 \mathrm{t} / \mathrm{ha}$ & 395 & 492 & 363 & $417 \mathrm{a}$ \\
$10 \mathrm{t} / \mathrm{ha}$ & 268 & 401 & 320 & $330 \mathrm{a}$ \\
\hline Rerata & $342 \mathrm{a}$ & $392 \mathrm{a}$ & $325 \mathrm{a}$ & $(-)$ \\
\hline
\end{tabular}

Keterangan: Angka pada baris dan kolom yang diikuti dengan huruf yang sama tidak berbeda nyata menurut uji DMRT $\alpha 5 \%$; $(-)$ : Tidak terjadi interaksi antar faktor.

\subsection{Diameter Buah}

Hasil sidik ragam (Anova) menunjukkan bahwa tidak terjadi interaksi antara takaran arang sekam padi dan takaran bokashi cair terhadap diameter buah. Takaran arang sekam padi juga tidak berpengaruh terhadap diameter buah tetapi data Tabel 6. menunjukkan bahwa buah dari tanaman yang tidak diberikan arang sekam padi cenderung lebih besar sedangkan buah dari tanaman yang diberikan arang sekam padi 5 t/ha dan 10 t/ha cenderung lebih kecil. Pemberian bokashi cair tidak berpengaruh nyata terhadap diameter buah tetapi buah dari tanaman yang diberikan bokashi cair dengan takaran $2 \mathrm{ml}$ per tanaman cenderung lebih besar sedangkan buah dari tanaman yang diberikan bokashi cair dengan takaran $4 \mathrm{ml}$ per tanaman paling kecil.

Tabel 6. Diameter Buah (cm)

\begin{tabular}{ccccc}
\hline \multirow{2}{*}{ Arang Sekam Padi } & \multicolumn{3}{c}{ Bokashi Cair } & \multirow{2}{*}{ Rerata } \\
\cline { 2 - 4 } & Kontrol & $2 \mathrm{ml}$ & $4 \mathrm{ml}$ & \\
\hline Kontrol & 6,0 & 6,1 & 5,8 & $6,0 \mathrm{a}$ \\
$5 \mathrm{t} / \mathrm{ha}$ & 5,9 & 5,8 & 5,4 & $5,7 \mathrm{a}$ \\
$10 \mathrm{t} / \mathrm{ha}$ & 5,5 & 5,8 & 5,7 & $5,7 \mathrm{a}$ \\
\hline Rerata & $5,8 \mathrm{a}$ & $5,9 \mathrm{a}$ & $5,6 \mathrm{a}$ & $(-)$ \\
\hline
\end{tabular}

Keterangan: Angka pada baris dan kolom yang diikuti dengan huruf yang sama tidak berbeda nyata menurut uji DMRT $\alpha 5 \%$; $(-)$ : Tidak terjadi interaksi antar faktor.

\subsection{Panjang Buah}

Hasil sidik ragam (Anova) menunjukkan bahwa tidak terjadi interaksi antara takaran arang sekam padi dan takaran bokashi cair terhadap panjang buah.

\section{Tabel 7. Panjang Buah $(\mathrm{cm})$}

\begin{tabular}{ccccc}
\hline \multirow{2}{*}{ Arang Sekam Padi } & \multicolumn{3}{c}{ Bokashi Cair } & \multirow{2}{*}{ Rerata } \\
\cline { 2 - 4 } & Kontrol & $2 \mathrm{ml}$ & $4 \mathrm{ml}$ & \\
\hline Kontrol & 16,2 & 18,3 & 17,0 & $17,1 \mathrm{a}$ \\
$5 \mathrm{t} / \mathrm{ha}$ & 16,3 & 15,7 & 14,7 & $15,6 \mathrm{a}$ \\
$10 \mathrm{t} / \mathrm{ha}$ & 14,2 & 16,8 & 14,9 & $15,3 \mathrm{a}$ \\
\hline Rerata & $15,6 \mathrm{a}$ & $16,9 \mathrm{a}$ & $15,5 \mathrm{a}$ & $(-)$ \\
\hline
\end{tabular}

Keterangan: Angka pada baris dan kolom yang diikuti dengan huruf yang sama tidak berbeda nyata menurut uji DMRT $\alpha 5 \%$; $(-)$ : Tidak terjadi interaksi antar faktor. 
Takaran arang sekam padi juga tidak berpengaruh terhadap panjang buah tetapi data Tabel 7. menunjukkan bahwa buah dari tanaman yang tidak diberikan arang sekam padi cenderung lebih panjang sedangkan buah dari tanaman yang diberikan arang sekam padi 10 t/ha paling pendek. Pemberian bokashi cair tidak berpengaruh nyata terhadap panjang buah tetapi buah dari tanaman yang diberikan bokashi cair dengan takaran $2 \mathrm{ml}$ per tanaman cenderung lebih panjang sedangkan buah dari tanaman yang diberikan bokashi cair dengan takaran $4 \mathrm{ml}$ per tanaman paling pendek.

\subsection{Berat Per Buah}

Hasil sidik ragam (Anova) menunjukkan bahwa tidak terjadi interaksi antara takaran arang sekam padi dan takaran bokashi cair terhadap berat per buah. Takaran arang sekam padi berpengaruh nyata terhadap berat per buah dimana buah dari tanaman yang tidak diberikan arang sekam padi paling berat dan berbeda nyata dengan berat per buah dari tanaman yang diberikan arang sekam padi dengan takaran $5 \mathrm{t} / \mathrm{ha}$ maupun $10 \mathrm{t} / \mathrm{ha}$. Pemberian bokashi cair tidak berpengaruh nyata terhadap berat per buah tetapi data Tabel 8 . menunjukkan bahwa buah dari tanaman yang diberikan bokashi cair dengan takaran $2 \mathrm{ml}$ per tanaman cenderung lebih berat sedangkan buah dari tanaman yang diberikan bokashi cair dengan takaran $4 \mathrm{ml}$ per tanaman paling ringan.

Tabel 8. Berat Per Buah (g)

\begin{tabular}{ccccc}
\hline \multirow{2}{*}{ Arang Sekam Padi } & \multicolumn{3}{c}{ Bokashi Cair } & \multirow{2}{*}{ Rerata } \\
\cline { 2 - 4 } & Kontrol & $2 \mathrm{ml}$ & $4 \mathrm{ml}$ & \\
\hline Kontrol & 253 & 351 & 253 & $285 \mathrm{a}$ \\
$5 \mathrm{t} / \mathrm{ha}$ & 263 & 185 & 169 & $206 \mathrm{~b}$ \\
$10 \mathrm{t} / \mathrm{ha}$ & 195 & 235 & 199 & $210 \mathrm{~b}$ \\
\hline Rerata & $237 \mathrm{a}$ & $257 \mathrm{a}$ & $207 \mathrm{a}$ & $(-)$
\end{tabular}

Keterangan: Angka pada baris dan kolom yang diikuti dengan huruf yang sama tidak berbeda nyata menurut uji DMRT $\alpha 5 \%$; $(-)$ : Tidak terjadi interaksi antar faktor.

\subsection{Jumlah Buah Per Tanaman}

Jumlah buah per tanaman yang dihasilkan sama banyak. Setiap tanaman sampel menghasilkan rata-rata enam buah selama penelitian dan setiap kali panen rata-rata setiap tanaman dipanen dua buah.

Tabel 9. Jumlah Buah Per Tanaman

\begin{tabular}{ccccc}
\hline \multirow{2}{*}{ Arang Sekam Padi } & \multicolumn{3}{c}{ Bokashi Cair } & \multirow{2}{*}{ Rerata } \\
\cline { 2 - 4 } & Kontrol & $2 \mathrm{ml}$ & $4 \mathrm{ml}$ & \\
\hline Kontrol & 6 & 6 & 6 & 6 \\
$5 \mathrm{t} / \mathrm{ha}$ & 6 & 6 & 6 & 6 \\
$10 \mathrm{t} / \mathrm{ha}$ & 6 & 6 & 6 & 6 \\
\hline Rerata & 6 & 6 & 6 & \\
\hline
\end{tabular}

\subsection{Berat Buah Per Tanaman}

Hasil sidik ragam (Anova) menunjukkan bahwa tidak terjadi interaksi antara takaran arang sekam padi dan takaran bokashi cair terhadap berat buah per tanaman. Takaran arang sekam padi berpengaruh nyata terhadap berat buah per tanaman dimana buah setiap tanaman yang tidak diberikan arang sekam padi paling berat dan berbeda nyata dengan berat buah per tanaman yang diberikan arang sekam padi dengan takaran $5 \mathrm{t} /$ ha maupun $10 \mathrm{t} / \mathrm{ha}$. Pemberian bokashi cair tidak berpengaruh nyata terhadap berat buah per tanaman tetapi data Tabel 10 . menunjukkan bahwa buah per tanaman yang diberikan bokashi cair dengan takaran $2 \mathrm{ml}$ per tanaman cenderung lebih berat sedangkan buah dari tanaman yang diberikan bokashi cair dengan takaran $4 \mathrm{ml}$ per tanaman paling ringan.

$\underline{\text { Tabel 10. Berat Buah Per Tanaman (g) }}$

\begin{tabular}{ccccc}
\hline \multirow{2}{*}{ Arang Sekam Padi } & \multicolumn{3}{c}{ Bokashi Cair } & \multirow{2}{*}{ Rerata } \\
\cline { 2 - 4 } & Kontrol & $2 \mathrm{ml}$ & $4 \mathrm{ml}$ & \\
\hline Kontrol & 1517 & 2104 & 1517 & $1713 \mathrm{a}$ \\
$5 \mathrm{t} / \mathrm{ha}$ & 1578 & 1109 & 1013 & $1233 \mathrm{~b}$ \\
$10 \mathrm{t} / \mathrm{ha}$ & 1167 & 1410 & 1194 & $1257 \mathrm{~b}$ \\
\hline Rerata & $1421 \mathrm{a}$ & $1541 \mathrm{a}$ & $1242 \mathrm{a}$ & $(-)$ \\
\hline
\end{tabular}

Keterangan: Angka pada baris dan kolom yang diikuti dengan huruf yang sama tidak berbeda nyata menurut uji DMRT $\alpha$ 5\%; ( - ): Tidak terjadi interaksi antar faktor.

\subsection{Jumlah Buah Per Petak}

Hasil sidik ragam (Anova) menunjukkan bahwa tidak terjadi interaksi antara takaran arang sekam padi dan takaran bokashi cair terhadap jumlah buah per petak. Takaran arang sekam padi berpengaruh nyata terhadap jumlah buah per petak dimana buah setiap petak dari tanaman yang diberikan arang sekam padi dengan takaran 5 t/ha paling banyak dan berbeda nyata dengan jumlah buah per petak dari tanaman yang tidak diberikan arang sekam padi tetapi berbeda nyata dengan jumlah buah per petak dari tanaman yang diberikan arang sekam padi dengan takaran 10 t/ha. Pemberian bokashi cair tidak berpengaruh nyata terhadap jumlah buah per petak tetapi data Tabel 11. menunjukkan bahwa buah per petak dari tanaman yang diberikan bokashi cair dengan takaran $2 \mathrm{ml}$ per tanaman cenderung lebih banyak sedangkan buah per petak dari tanaman yang tidak diberikan bokashi cair paling sedikit.

\begin{tabular}{|c|c|c|c|c|}
\hline \multirow{2}{*}{ Arang Sekam Padi } & \multicolumn{3}{|c|}{ Bokashi Cair } & \multirow{2}{*}{ Rerata } \\
\hline & Kontrol & $2 \mathrm{ml}$ & $4 \mathrm{ml}$ & \\
\hline Kontrol & 45417 & 51250 & 51667 & 49444 b \\
\hline $5 \mathrm{t} / \mathrm{ha}$ & 57083 & 55417 & 54583 & $55694 \mathrm{a}$ \\
\hline $10 \mathrm{t} / \mathrm{ha}$ & 52917 & 53750 & 53750 & $53472 \mathrm{ab}$ \\
\hline Rerata & $51806 \mathrm{a}$ & $53472 \mathrm{a}$ & $53333 \mathrm{a}$ & $(-)$ \\
\hline
\end{tabular}

Keterangan: Angka pada baris dan kolom yang diikuti dengan huruf yang sama tidak berbeda nyata menurut uji DMRT $\alpha 5 \%$; $(-)$ : Tidak terjadi interaksi antar faktor.

\subsection{Berat Buah Per Petak}

Hasil sidik ragam (Anova) menunjukkan bahwa tidak terjadi interaksi antara takaran arang sekam padi dan takaran bokashi cair terhadap berat buah per petak. Takaran arang sekam padi juga tidak berpengaruh nyata terhadap berat buah per petak setiap kali panen tetapi data Tabel 12. menunjukkan bahwa buat setiap petak yang diberikan arang sekam padi dengan takaran $5 \mathrm{t} /$ ha cenderung selalu lebih berat setiap kali panen hingga perhitungan total panen.

Pemberian bokashi cair berpengaruh nyata terhadap berat buah per petak pada saat panen I dan perhitungan total panen dimana pemberian bokashi cair dengan takaran $4 \mathrm{ml}$ per tanaman memberikan hasil buah yang paling berat setiap petaknya. Saat panen II dan panen III, pemberian bokashi cair tidak menunjukkan pengaruh yang nyata tetapi buah yang dihasilkan dari tanaman yang diberikan bokashi cair $4 \mathrm{ml}$ per tanaman tetap cenderung lebih berat.

\section{Tabel 122. Berat Buah Per Petak (t/ha)}

\begin{tabular}{|c|c|c|c|c|c|}
\hline \multirow{2}{*}{$\begin{array}{c}\text { Waktu } \\
\text { Pengamatan }\end{array}$} & \multirow{2}{*}{$\begin{array}{c}\text { Arang } \\
\text { Sekam Padi }\end{array}$} & \multicolumn{3}{|c|}{ Bokashi Cair } & \multirow{2}{*}{ Rerata } \\
\hline & & Kontrol & $2 \mathrm{ml}$ & $4 \mathrm{ml}$ & \\
\hline \multirow{4}{*}{ Panen I } & Kontrol & 6,458 & 5,958 & 7,542 & $6,653 \mathrm{a}$ \\
\hline & $5 \mathrm{t} / \mathrm{ha}$ & 5,417 & 7,083 & 9,333 & $7,278 \mathrm{a}$ \\
\hline & $10 \mathrm{t} / \mathrm{ha}$ & 4,500 & 5,250 & 7,167 & $5,639 a$ \\
\hline & Rerata & $5,458 \mathrm{~b}$ & $6,097 \mathrm{ab}$ & $8,014 \mathrm{a}$ & $(-)$ \\
\hline \multirow{4}{*}{ Panen II } & Kontrol & 4,042 & 4,375 & 3,292 & $3,903 \mathrm{a}$ \\
\hline & $5 \mathrm{t} / \mathrm{ha}$ & 4,792 & 3,125 & 6,625 & $4,847 \mathrm{a}$ \\
\hline & $10 \mathrm{t} / \mathrm{ha}$ & 3,458 & 3,333 & 4,083 & $3,625 \mathrm{a}$ \\
\hline & Rerata & $4,097 \mathrm{a}$ & $3,611 \mathrm{a}$ & $4,667 \mathrm{a}$ & $(-)$ \\
\hline \multirow{4}{*}{ Panen III } & Kontrol & 3,042 & 3,667 & 4,250 & $3,653 \mathrm{a}$ \\
\hline & $5 \mathrm{t} / \mathrm{ha}$ & 3,875 & 4,667 & 3,833 & $4,125 \mathrm{a}$ \\
\hline & $10 \mathrm{t} / \mathrm{ha}$ & 4,708 & 4,083 & 4,667 & $4,486 \mathrm{a}$ \\
\hline & Rerata & $3,875 \mathrm{a}$ & $4,139 \mathrm{a}$ & $4,250 \mathrm{a}$ & $(-)$ \\
\hline \multirow{4}{*}{ Total Panen } & Kontrol & 13,542 & 14,000 & 15,083 & $14,208 \mathrm{a}$ \\
\hline & $5 \mathrm{t} / \mathrm{ha}$ & 14,083 & 14,875 & 19,792 & $16,250 \mathrm{a}$ \\
\hline & $10 \mathrm{t} / \mathrm{ha}$ & 12,667 & 12,667 & 15,917 & $13,750 \mathrm{a}$ \\
\hline & Rerata & $13,431 \mathrm{~b}$ & $13,847 \mathrm{~b}$ & $16,931 \mathrm{a}$ & $(-)$ \\
\hline
\end{tabular}

Keterangan: Angka pada baris dan kolom yang diikuti dengan huruf yang sama tidak berbeda nyata menurut uji DMRT $\alpha 5 \% ;(-)$ : Tidak terjadi interaksi antar faktor.

\subsection{Berat Segar Berangkasan}

Hasil sidik ragam (Anova) menunjukkan bahwa tidak terjadi interaksi antara takaran arang sekam padi dan takaran bokashi cair terhadap berat segar berangkasan. Takaran arang sekam padi berpengaruh terhadap berat segar berangkasan dimana berangkasan segar dari tanaman yang tidak diberikan arang sekam padi paling berat dan berbeda nyata dengan berat kering berangkasan dari tanaman yang diberikan arang sekam padi 10 t/ha tetapi tidak berbeda nyata dengan berat kering berangkasan dari tanaman yang diberikan arang sekam padi 5 t/ha. Pemberian bokashi cair juga berpengaruh nyata terhadap berat segar berangkasan dimana berangkasan segar dari tanaman yang diberikan bokashi cair dengan takaran $4 \mathrm{ml}$ per tanaman paling berat dan berbeda nyata dengan berat segar berangkasan dari tanaman yang tidak diberikan bokashi cair tetapi tidak berbeda nyata dengan berat segar berangkasan dari tanaman yang diberikan bokashi cair dengan takaran $2 \mathrm{ml}$ per tanaman.

Tabel 13. Berat Segar Berangkasan (t/ha)

\begin{tabular}{ccccc}
\hline \multirow{2}{*}{ Arang Sekam Padi } & \multicolumn{3}{c}{ Bokashi Cair } & \multirow{2}{*}{ Rerata } \\
\cline { 2 - 4 } & Kontrol & $2 \mathrm{ml}$ & $4 \mathrm{ml}$ & \\
\hline Kontrol & 7,500 & 8,542 & 9,125 & $8,389 \mathrm{a}$ \\
$5 \mathrm{t} / \mathrm{ha}$ & 6,250 & 6,750 & 7,667 & $6,889 \mathrm{ab}$ \\
$10 \mathrm{t} / \mathrm{ha}$ & 4,000 & 5,875 & 8,667 & $6,181 \mathrm{~b}$ \\
\hline Rerata & $5,917 \mathrm{~b}$ & $7,056 \mathrm{ab}$ & $8,486 \mathrm{a}$ & $(-)$ \\
\hline
\end{tabular}

Keterangan: Angka pada baris dan kolom yang diikuti dengan huruf yang sama tidak berbeda nyata menurut uji DMRT $\alpha 5 \%$; ( - ): Tidak terjadi interaksi antar faktor.

\subsection{Berat Kering Berangkasan}

Hasil sidik ragam (Anova) menunjukkan bahwa tidak terjadi interaksi antara takaran arang sekam padi dan takaran bokashi cair terhadap berat kering berangkasan. Takaran arang sekam padi juga tidak berpengaruh terhadap berat kering berangkasan tetapi data Tabel 14. menunjukkan bahwa berangkasan kering dari tanaman yang tidak diberikan arang sekam padi cenderung lebih berat sedangkan berangkasan kering dari tanaman yang diberikan arang sekam padi 10 
t/ha paling ringan. Pemberian bokashi cair juga berpengaruh nyata terhadap berat kering berangkasan dimana berangkasan kering dari tanaman yang diberikan bokashi cair dengan takaran $4 \mathrm{ml}$ per tanaman paling berat dan berbeda nyata dengan berat kering berangkasan dari tanaman yang diberikan bokashi cair dengan takaran $2 \mathrm{ml}$ per tanaman tetapi tidak berbeda nyata dengan berat kering berangkasan dari tanaman yang tidak diberikan bokashi cair.

Tabel 14. Berat Kering Berangkasan (t/ha)

\begin{tabular}{ccccc}
\hline \multirow{2}{*}{ Arang Sekam Padi } & \multicolumn{3}{c}{ Bokashi Cair } & \multirow{2}{*}{ Rerata } \\
\cline { 2 - 4 } & Kontrol & $2 \mathrm{ml}$ & $4 \mathrm{ml}$ & \\
\hline Kontrol & 1,875 & 1,417 & 2,375 & $1,889 \mathrm{a}$ \\
$5 \mathrm{t} / \mathrm{ha}$ & 2,250 & 1,417 & 1,750 & $1,806 \mathrm{a}$ \\
$10 \mathrm{t} / \mathrm{ha}$ & 1,333 & 1,583 & 1,625 & $1,514 \mathrm{a}$ \\
\hline Rerata & $1,819 \mathrm{ab}$ & $1,472 \mathrm{~b}$ & $1,917 \mathrm{a}$ & $(-)$ \\
\hline \multirow{2}{*}{ Kennnn}
\end{tabular}

Keterangan: Angka pada baris dan kolom yang diikuti dengan huruf yang sama tidak berbeda nyata menurut uji DMRT $\alpha 5 \%$; $(-)$ : Tidak terjadi interaksi antar faktor.

\subsection{Indeks Panen}

Hasil sidik ragam (Anova) menunjukkan bahwa tidak terjadi interaksi antara takaran arang sekam padi dan takaran bokashi cair terhadap indeks panen. Takaran arang sekam padi berpengaruh nyata terhadap indeks panen dimana indeks panen dari tanaman yang diberikan arang sekam padi dengan takaran 5 t/ha paling tinggi dan berbeda nyata dengan indeks panen dari tanaman yang tidak diberikan arang sekam padi tetapi tidak berbeda nyata dengan indeks panen dari tanaman yang diberikan arang sekam padi $10 \mathrm{t} / \mathrm{ha}$. Pemberian bokashi cair tidak berpengaruh nyata terhadap indeks panen tetapi data Tabel 15 . menunjukkan bahwa indeks panen tanaman yang tidak diberikan bokashi cair cenderung lebih tinggi.

Tabel 15. Indeks Panen (\%)

\begin{tabular}{ccccc}
\hline \multirow{2}{*}{ Arang Sekam Padi } & \multicolumn{3}{c}{ Bokashi Cair } & \multirow{2}{*}{ Rerata } \\
\cline { 2 - 4 } & Kontrol & $2 \mathrm{ml}$ & $4 \mathrm{ml}$ & \\
\hline Kontrol & 64,4 & 61,5 & 62,2 & $62,7 \mathrm{~b}$ \\
$5 \mathrm{t} / \mathrm{ha}$ & 69,8 & 69,3 & 72,9 & $70,7 \mathrm{a}$ \\
$10 \mathrm{t} / \mathrm{ha}$ & 75,8 & 68,2 & 63,9 & $69,3 \mathrm{a}$ \\
\hline Rerata & $70,0 \mathrm{a}$ & $66,3 \mathrm{a}$ & $66,3 \mathrm{a}$ & $(-)$ \\
\hline
\end{tabular}

Keterangan: Angka pada baris dan kolom yang diikuti dengan huruf yang sama tidak berbeda nyata menurut uji DMRT $\alpha 5 \% ;(-)$ : Tidak terjadi interaksi antar faktor.

\section{Simpulan}

Pengaruh interaksi antara takaran arang sekam padi dan bokashi cair hanya terjadi terhadap suhu tanah 35 HST. Takaran arang sekam padi berpengaruh nyata terhadap suhu tanah 14 HST, berat per buah, berat buah per tanaman, jumlah buah per petak, berat segar berangkasan dan indeks panen. Takaran bokashi cair berpengaruh nyata terhadap berat buah per petak panen I dan total panen, berat segar berangkasan dan berat kering berangkasan. Pemberian arang sekam padi 5 t/ha memberikan hasil terbaik berupa 55694 buah setiap hektar dengan berat 16,250 ton. Pemberian bokashi cair $4 \mathrm{ml}$ per tanaman memberikan hasil 53333 buah setiap hektar dengan berat 16,931 ton.

\section{Pustaka}

Budhyastoro, T., Tala'ohu, S.H. \& Watung, R.L. 2006. Pengukuran Suhu Tanah. Sifat Fisik Tanah dan Metode Analisisnya. Bogor: Balai Besar Penelitian dan Pengembangan Sumberdaya Lahan Pertanian.

Gomez, K.A. \& Gomez, A.A. 1984. Statistical Procedures for Agricultural Research. New York: John Wiley \& Sons.

Higa, T. 1991. Effective microorganisms: A biotechnology for mankind. Proceedings of the first international conference. Kyusei nature farming. Washington, DC, USA: US Department of Agriculture, hal.8-14.

Kolo, A. \& Raharjo, K.T.P. 2016. Pengaruh Pemberian Arang Sekam Padi dan Frekuensi Penyiraman terhadap Pertumbuhan dan Hasil Tanaman Tomat (Lycopercicom esculentum Mill). Savana Cendana, 1(03): 102-104.

Lolomsait, Y. 2016. Pengaruh Takaran Arang Sekam Padi dan Frekuensi Penyemprotan Pupuk Organik Cair terhadap Pertumbuhan dan Hasil Tanaman Cabe Merah (Capsicum annum L.). Savana Cendana, 1(04): 125127

Noor, M. 2004. Lahan Rawa: Sifat dan Pengelolaan Tanah Bermasalah Sulfat Masam. Depok: Raja Grafindo Persada.

Nurita \& Jumberi, A. 1997. Pemupukan KCl dan Abu Sekam pada Padi Gogo di Tanah Podsolik Merah Kuning. Prosiding Seminar. Pembangunan Pertanian Berkelanjutan Menyongsong Era Globalisasi. Banjarbaru: Peragi Komisariat Kalimantan Selatan.

Poerwowidodo, M. 'ud 1993. Telaah Kesuburan Tanah. Bandung: Angkasa.

Radjagukguk, B. \& Jutono 1983. Alternatif-Alternatif Pelaksanaan Program Pengapuran Lahan-Lahan Mineral Masam Indonesia. Prosiding Seminar. Yogyakarta: Fakultas Pertanian Universitas Gadjah Mada.

Rukmana, R. 1994. Budidaya Mentimun. Yogyakarta: Kanisius.

Syahruzad, A. 1987. Pengaruh Dosis Hyponex Biru dan Jenis Media Tumbuh Terhadap Pertumbuhan dan Produksi Tomat. Skripsi. Banjarbaru: Fakultas Pertanian Unlam.
Tyndall 1987. Historical source of cucumber plants. London: The Macmillan Press ltd.

Yadav, A., Yadav, T. \& Chaudhary, B. 1979. Path coefficient analysis of the association of physiological traits with grain yield and harvest index in greengram [India]. Indian Journal of Agricultural Sciences, (49): 86-90. 